\title{
RECEPÇÃO INFANTIL DA OBRA TEATRAL
}

\section{Percepção, envolvimento e fruição são elementos para análise da recepção infantil do espetáculo teatral}

A partir do ano passado, o Ente Teatrale Italiano juntou-se ao tradicional Stregagatto-prêmio às melhores produções de teatro para a infância e a juventude do ano - em um projeto intitulado O Tempo do Espectador, com o objetivo de instituir uma comissão permanente para o tema do receptor, entendido este como "o eixo em torno do qual giram todos os projetos artísticos e organizativos do teatro para as novas gerações."

Para a temporada 97-98, o projeto envolveu quinze centros de teatro para a juventude, 25 espetáculos articulados sobre cinco diferentes temáticas, cerca de 1.700 espectadores entre 3 e 14 anos, um aguerrido conjunto de examinadores (escolhidos dos centros) e a autora deste trabalho, encarregada de oferecer indicações metodológicas para pesquisar e analisar o material recolhido através de uma indicação global de leitura e reflexão.

A pesquisa foi desenvolvida por meio de um questionário aberto, diversificado para as diversas faixas de idade e para as diversas áreas temáticas sobre as quais versavam os espetáculos. A esse instrumento de pesquisa, que recolheu predominantemente juízos, por assim dizer, explícitos e mediatos da expressão escrita, foram somadas as observações dos examinadores, que procuraram os sujeitos da

\section{A AUTORA}

\section{Mafra Gagliardi}

Professora do Departamento de Ciências da Educação da Universidade de Padova, Itália. amostragem depois de cada espetáculo para recolher as reações mais imediatas e espontâneas através de uma atividade de brainstorming .

Foi possível, dessa forma, evidenciar alguns pontos nodais da relação teatro-espectador criança: o envolvimento operado pelo espetáculo, a sua interpretação em um plano semântico, semiótico e emotivo, os mecanismos de identificação e projeção e a relação com a experiência pregressa do espectador.

Do material recolhido, emerge claramente o difundido e generalizado prazer que acompanha a recepção teatral pela criança. Num leque de adjetivos propostos para qualificar um espetáculo, as crianças escolhem, constantemente, em primeiro lugar, a palavra divertido. Esse adjetivo parece coincidir, em qualquer caso, com cômico, mas o fato de vir atribuído indiscriminadamente a todos os espetáculos - inclusive àqueles com tom predominantemente dramático ou trágico, vinculado ainda a outros adjetivos, como emocionante, triste, amedrontador - implica a necessidade de algum aprofundamento.

O espetáculo teatral é visto como uma situação na qual, a todo instante, se produzem estímulos lingüísticos, sonoros, visuais, gestuais e plásticos (cada qual pertencente a um sistema de códigos distinto), que suscitam um prazer de tipo sensorial.

A recepção infantil revela, em primeiro plano, o impacto produzido pela obra artística: a atenção aos aspectos materiais e expres- 
sivos do espetáculo - nos quais reside sua especificidade semiótica - é muito mais viva no espectador criança do que no adulto. É muito ampla sua capacidade de extrair imagens e ritmos da linguagem teatral: cenas inteiras de um espetáculo foram reconstruídas de memória com uma exatidão de detalhes muitas vezes surpreendente. Muito freqüentemente a alternância escuro/luz, a intensidade das cores e a sugestão da música vêm citados como fontes de intensa emoção.

O espectador infantil goza a história representada e a modalidade de representação, não se limitando a atribuir um sentido àquilo que está oculto na cena - como faz o espectador adulto - mas está atento àquilo que se $f a z$ na cena, isto é, ao aqui e agora da representação, que é o real artístico.

Nesse sentido, se o fruidor é etimologicamente aquele que desfruta de um direito ou de um bem, a fruição de uma obra de arte (em particular da obra de arte teatral) comporta um gozo no qual pode estar incluída a aquisição de um bem, prazer ou divertimento.

\section{SIMPLES, DIFÍCIL, CÔMICO...}

Surpreende, nos textos das crianças, também a freqüência com que recorrem, em relação a um espetáculo, ao adjetivo simples. $\mathrm{O}$ adjetivo, caracterizado nesse contexto por uma certa ambigüidade semântica, é usado com conotação nitidamente positiva para indicar a simplicidade dos meios usados em cena em relação à produção de sentido. Causa espanto $\mathrm{e}$ admiração o fato de objetos pobres ou insólitos adquirirem significado na cena; de uma história ou algumas idéias complexas adquirirem corpo em matérias sensíveis e em objetos ou gestos cotidianos. Os espectadores captam agudamente aquela que é uma peculiaridade da linguagem teatral: sua capacidade de reinventar o significado das coisas e nossa relação com ele; a sua fundamental simplicidade metafórica, ao contrário da sobrecarga da ficção televisiva e cinematográfica.

Em outros casos, ao contrário, simples é usado pelas crianças com carga depreciativa quando falam de espetáculos julgados infantis, adequados a crianças menores. Muito simples, portanto, sem interesse. Verificase que o adjetivo é usado em oposição a difí$c i l$, termo que vem aplicado àqueles espetáculos que, segundo as crianças, comportam dificuldade de representação e são difíceis, então, para os atores. Mas difícil, pode vir ligado a complicado, revelando problemas de compreensão pelos espectadores. Isso se verifica, porém, em grau claramente menor ao defendido pelos professores (um questionário à parte os interrogava a respeito), fato que se deduz das várias respostas indiretas que nos deram, por exemplo, os títulos alternativos dados aos vários espetáculos. Os jovens também encontram dificuldade na decifração de uma cena, mas conseguem captar, de qualquer forma, o sentido global da mensagem.

Parece, de fato, que o prazer da fruição deriva tanto dos signos transparentes de um espetáculo quanto daqueles opacos, isto é, que resistem à atribuição de sentido. Aliás, freqüentemente o signo opaco provoca o espectador na sua inventividade para construir uma relação com a sua inteligibilidade.

Esse processo, naturalmente, tem seus limites: se o espetáculo é muito complicado, a criança espectadora se desencoraja e abandona o campo, mas, se é muito simples, vê-se indubitavelmente privada de um prazer. Vale notar, por outro lado, que os dois adjetivos com conotação decisivamente negativa, monótono e estúpido, que também aparecem registrados nos questionários, raramente são associados a complicado ou difícil, mas geralmente aparecem relacionados (estúpido/monótono). 
Um outro adjetivo muito recorrente na qualificação dos espetáculos é cômico. Não há dúvida de que as crianças riem muito e com prazer no teatro. Riem por princípio e por contágio: o cômico, como se sabe, é um fato eminentemente social e o grupo é um dispositivo inigualável para aumentar a sua intensidade. Toda manifestação de comicidade em cena é imediatamente percebida e calorosamente sublinhada: as motivações de riso constituem um fato recorrente para se estimular parentes e amigos a ver o espetáculo. Às vezes, os espetáculos colocam em evidência uma comicidade verbal à qual as crianças menores parecem particularmente sensíveis. A palavra é usada além de sua função semântica, como objeto sonoro portador de aliterações, onomatopéias, nonsense. Freqüentemente elas percebem também o cômico da situação ligada à transgressão de uma norma. Em particular a comicidade chula, condenada pela boa educação, é acolhida e destacada com exaltação.

Mas, pelo fato de estar incluída nas expectativas do jovem espectador, a comicidade pode também prender a sua atenção, limitando-a a uma fruição superficial, que o impede de captar toda a amplitude da proposta cênica. A análise das reações diversas a um mesmo espetáculo trouxe à luz as dinâmicas desse gênero.

Durante a audiência a um espetáculo, pode-se depreender também que, se a sugestão da cena é muito intensa, os espectadores experimentam um certo medo. Para as crianças menores, o medo parece ser provocado, mais que pela situação, por estímulos à percepção, particularmente determinadas cores, como o vermelho e o negro, e por sons imprevistos e muito fortes. Em linhas gerais, porém, o espectador pode sentir medo em qualquer momento do espetáculo, sem que isso atrapalhe o prazer da fruição. $\mathrm{O}$ adjetivo pavoroso é acompanhado por avaliações como divertido, bonito, estupendo, e as mesmas cenas indicadas por alguns dos espectadores como portadoras de medo são citadas por outros como as mais agradáveis. Estamos então em presença daquilo que Antonio Faeti define como o prazer excitante e isento de causar medo que a literatura infantil já há muito tempo reconheceu e valorizou. $\mathrm{O}$ teatro permite experimentálo em uma situação protegida, constituída da proximidade entre os espectadores e da consciência coletiva da ficção.

Da totalidade das respostas das crianças fica confirmado que o espetáculo teatral opera sobre elas um forte envolvimento emocional conjunto. Ativam-se mecanismos complexos de identificação e de projeção: desejam ser uma certa personagem, viver com ela uma determinada situação.

Junto com o prevalente e mais óbvio ensimesmamento, em relação ao herói ou à heroína de um espetáculo, aflora uma outra forma de identificação com personagens totalmente negativas, nas quais o espectador projeta as próprias pulsões agressivas, enfatizando as conotações de violência também além da sua presença efetiva no espetáculo. Ainda nesse caso, parece evidente o prazer de experimentar comportamentos transgressores na dimensão protegida da ficção cênica.

Aquilo que resulta aceitável e até mesmo liberador no plano do imaginário é condenado no plano da realidade. Se entrasse em casa ou na escola (hipótese colocada numa pergunta do questionário) a personagem malvada seria drasticamente eliminada por aqueles mesmos espectadores que com ela apaixonadamente se identificaram.

A atribuição de significado a um espetáculo mobiliza todo o sistema de referências das crianças. Na cena se desenvolvem as histórias 
de Pinóquio, da Baleia Branca, dos índios da América ou da Chapeuzinho Vermelho. Mas, através dessas histórias, o espetáculo fala ao espectador também e sobretudo de si mesmo. De qualquer forma, funciona como espelho. A decifração do sentido se radica então no background afetivo do espectador, que institui parâmetros de confronto entre a situação cênica e a própria experiência da realidade. Ele pode concordar com a história representada, mas também refutá-la, distanciando-se dela, sempre com uma postura receptiva, caracterizada por uma intensa participação (seria interessante verificar se essa atividade se mantém com a mesma pertinência também na fruição televisiva).

Do material coletado pela pesquisa fazem parte muitos desenhos produzidos sobretudo por crianças da escola maternal e do primeiro ciclo elementar. São recorrentes, com notável força expressiva, imagens que atingiram com mais impacto os espectadores, em particular as cenas de medo, e as cômicas, e retratos das personagens que permaneceram com maior vigor no imaginário do espectador. São muito interessantes as modalidades de configuração do espaço cênico, das fontes de luz, das cores e dos objetos presen-

Resumo: $\mathrm{O}$ artigo contém a descrição e a análise dos resultados de uma pesquisa sobre a recepção infantil do espetáculo teatral. A partir dos resultados, a autora pôde tirar conclusões com relação ao distanciamento e à interação do público infantil com a obra, que, na sua complexidade, é vista como uma situação na qual, a todo instante, se produzem estímulos lingüisticos, sonoros, visuais, gestuais e plásticos (cada qual pertencente a um sistema de códigos distinto), que suscitam um prazer de tipo sensorial. A partir dos desenhos realizados pelos sujeitos da pesquisa, a autora concluiu também que há forte envolvimento e mobilização perceptiva por parte das crianças, inclusive de faixas etárias mais baixas.

Palavras-chave: teatro, recepção infantil, fruição teatral, espectador tes em cena, que são, em última instância, a confirmação de uma extraordinária capacidade de percepção e de registro do olhar infantil.

Um bom número de desenhos revela a forte percepção que as crianças, sobretudo das faixas etárias mais baixas, têm do público que as rodeia. Os espectadores vêm representados junto com as personagens e os objetos de cena, conjugados ao mesmo clímax. De qualquer forma, eles aparecem alinhados frontalmente, em pé ou sentados, seguem a cena ou se olham (a testemunhar uma relação presente na sala, na qual o espectador olha e é olhado pelos companheiros). Outras vezes, são representados com seus nomes, como numa história em quadrinhos, ou retratados em duplas ou em grupos, enquanto gritam "bravo" aos atores.

O fato de partilhar a fruição teatral com um grupo coetâneo e de firmar com todos os outros espectadores, juntos, um mesmo contrato de "suspensão da incredulidade" (Mannoni) é vivido pelas crianças com particular intensidade. Pode aflorar nelas a compreensão daquilo que é um elemento constitutivo do evento teatral: envolver atores e espectadores numa forma de comunhão e criar uma comunidade forte.

Abstract: The article has a description and the analysis of the results of a research project on child reception of theater plays. Based on the results reached, the author was able to come to conclusions on the distancing and interaction of the child public with the work, which, in its complexity, is seen as a situation in which, at every moment, language, sound, visual, gesture and plastic stimuli are produced (each belonging to a distinct code system), that cause sensorial pleasure. Based on drawings made by the research subjects, the author also concluded there is strong involvement and perceptive mobilizing by the children, including among the lower age groups.

Key words: theater, child reception, theater fruition, spectator 